\title{
Coexistence of wildlife with modern tourism: the context of Bangladesh
}

\author{
Sharmin Sultana \\ Majharul Islam \\ Sk Zahin Arabi
}

Tourism and Hospitality Management

Daffodil International University, Bangladesh

\section{Keywords}

Wildlife, Sustainability, Domestic Tourism, Tourist and Travelers, Local community, Society.

\begin{abstract}
Wildlife is an essential element of our environment for the ecosystem to maintain the ecological balance. Tourism is also a crucial factor for the development of our infrastructure, economy, and social well-being. Tourism plays a positive role in our economy by directly and indirectly involving different industries and generating revenues, but tourism also plays a different role to the society and the environment as more people cause more pollution. The industry of domestic tourism has been on bloom before covid-19. As nature recalls the natural resources are now better than before. Various occasions are counted, and important measures are taken into account. It also shows how the industries are harming the wildlife situations alongside the locals in those selected areas. The aim of this study is to find a way to establish a sustainable tourism specially giving emphasis on wildlife. This research goes deep with the altercation of human thinking as a local and also as a tourist. Data were collected through a structured questionnaire survey from 140 respondents following a random sampling method. SPSS software was used for data analysis. The statistical findings reveal that tourists are indirectly involved with reduction of wildlife species in Bangladesh. The industry of domestic tourism has been on bloom before covid-19. As nature recalls the natural resources are now better than before. Various occasions are counted, and important measures are taken into account. It also shows how the industries are harming the wildife situations alongside the locals in those selected areas. The findings of this study might help reshape the tourism industry and find ways for coexisting of wildlife with modern tourism.
\end{abstract}

\section{Introduction}

Co-existence of wildlife with modern tourism should be the main considerations in developing sustainable tourism in Bangladesh. Local and international tourists are considered as the main and direct interaction to the wildlife. Bangladesh most likely has different situations based on nature and wildlife as it is a green country and majority of the people are accounted for with nature itself. Through the research people were segmented in different ways in order to achieve different responses which are analyzed. The research argues with the statement "Co-existence of wildlife with tourism". It argues with the society's current barriers and common practices as that effect directly with the wildlife.

The conflict of human and wildlife has contributed to the extinction of numerous species (Woodroffe R, Thirgood S, Rabinowitz A, eds. 2005) as people look for new places to live and sustain. Human communications with untamed life are frequently outlined adversely regardless of whether significant positive advantages - recreational, instructive, mental, and environment administrations exist (Soulsbury CD, White PCL. 2015). Human-untamed life strife has critical ramifications for human wellbeing, security, and government assistance, just as biodiversity and biological system wellbeing. Effects on people can be immediate or aberrant. Human injury and demise can result when creatures nibble, paw, gore, or in any case legitimately assault individuals; during impacts among creatures and autos, trains, planes, boats and sends, and different vehicles; and from the transmission of a zoonotic infection or parasite (Conover MR. 2002).

It has been seen that humans and wildlife have a long history of conflict which caused humans to do harm to nature. Thus, tourism can lead to various problems such as disease and virus outbreak. This study sees that limitation and tries to find problems that can be solved. Travel and tourists have very little 
patience for protecting nature or wildlife because of the lack of ethical practice and education. Though the majority of tourists and travelers are students they are unaware of the situation that they might create especially in the context of Bangladesh. A key finding was the requirement for wildlife tourism researchers to emphasize their fondness with the paradigmatic situation of the natural sciences in their research activities. A significant challenge in realizing future open doors is accomplishing interdisciplinary research, where natural and social researchers cooperatively characterize, and address concerns related with sustainably overseeing wildlife tourism. (Kate Rodger, Susan A. Moore \& David Newsome 2010)

The relation between wildlife and humans are long history but through tourism it has started to come to light.

\section{Literature review}

The values of conservation, animal welfare, visitor satisfaction, and profitability are often in conflict in wildlife tourism (WT) and trade-offs are necessary. While there is a range of factors involved, the most germane are impact on the environment and quality of the experience. Sustainable tourism depends on encouraging the desirable and discouraging the undesirable. (Paul C Reynolds, Dick Braithwaite, 2001)

Tourists enjoy the Nature's design, performance and immense biodiversity which start a passionate reaction of 'wonderful', marvel and advantage that opens eco centric and human associations with wild creatures and an inclination that is 'incredible'. There is an ideal opportunity to stand and gaze and think about. Nature and untamed life are spatial occasions as well as transient ones. In this limited encapsulated space of an untamed life experience, socially built present day quick time scatters and is supplanted by tranquility and nature's time whereby members are completely invested in the exhibition. (Susanna Curtin, 2009).

The emphasis on human-wildlife life struggle has frequently been an imperative to wildlife protection, as professionals have fixated their consideration on diminishing negative connections, instead of on expanding positive relations among people and untamed life. To run after arrangements that augment protection achievement, it is important to incorporate positive co-operations, conjunction, and mentalities of resistance toward untamed life. (Beatrice Frank, 2016)

Support in wildlife-based community tourism inside and around secured regions is viewed as an apparatus to connect biodiversity preservation and community occupations improvement. However, there is an insufficiency of frameworks at present used to get unpredictable and dynamic connections that exist among protection, tourism, and improvement. The community capitals structure is received to survey these linkages from a framework thinking point of view in which community capitals' stock and stream, clarified by a community's investment in tourism decides the course of progress. (Moren Tibabo Stone \& Gyan P. Nyaupane, 2018)

Wildlife tourism epitomizes many of the research and management issues confronting those working at the interface of society and natural resources. Little is currently known about this interface, especially the impacts resulting from interactions between people and the wildlife on which this industry depends. (Kate Rodger, Susan A. Moore \& David Newsome 2010).

\section{Research methodology}

This research has been conducted with quantitative research methodology. Secondary research data were also used, and some group discussions are also conducted through various steps. But the nature of this study is quantitative. Standard questionnaire was used which had closed ended questions. Data was collected from different places of Bangladesh. Group discussions were only to get a better perspective for the initial research and data analysis.

\section{Findings}

The total numbers of respondents were 140 members. There were a lot of suggestions from different people at different places.

The demographic segmentation of respondents is, Gender, Age, Nationality and Occupation which are presented below: 


\begin{tabular}{|l|l|}
\hline Gender & Ratio \\
\hline Male & $67.9 \%$ \\
\hline Female & $32.1 \%$ \\
\hline
\end{tabular}

Table 1: Gender

Female travelers were not that popular a few years ago but recently it has started to grow and now it has a steady pace of getting better.

\begin{tabular}{|l|l|}
\hline Age & Ratio \\
\hline $15-20$ years & $7.1 \%$ \\
\hline $21-30$ years & $83.9 \%$ \\
\hline 31 and above & $8.9 \%$ \\
\hline
\end{tabular}

Table 1.2: Age

The age is a very important factor as tourists and travelers consist of different ages. But Bangladesh has a very few numbers of senior citizens who are tourists or travelers. Majority of the travelers are below 31 years old.

\begin{tabular}{|l|l|}
\hline Nationality & Ratio \\
\hline Bangladeshi & $100 \%$ \\
\hline
\end{tabular}

Table: 1.3 Nationalities

All of the respondents were Bangladeshi.

\begin{tabular}{|l|l|}
\hline Occupation & Ratio \\
\hline Student & $52 \%$ \\
\hline Part time service holder/ Business owner & $28 \%$ \\
\hline Service holder & $20 \%$ \\
\hline
\end{tabular}

Table: 1.4 Occupations

Majority of the tourists and travelers in Bangladesh are students. As they have a greater chance of tour and travel. The majority of respondents were students and others were different service holders.

Here is the descriptive statistics which provides the standard deviation and mean of the variables:

\begin{tabular}{|l|l|l|}
\hline Variables & Mean & Standard Deviation \\
\hline Do you think Domestic tourism is Suitable in the contrast of Bangladesh? & 3.8909 & 1.24235 \\
\hline Do you think Domestic tourism will impact the economy of our country & 4.2500 & .69413 \\
\hline Do you think Bangladesh promotes wildlife safety enough? & 1.9821 & .79752 \\
\hline Do you think Bangladesh can promote Tourism through Wildlife & 3.4286 & 1.29133 \\
\hline $\begin{array}{l}\text { Is the government of Bangladesh taking necessary steps to preserve its } \\
\text { wildlife? }\end{array}$ & 2.8571 & 1.36753 \\
\hline Do you think Domestic Tourism is interrupting the ecosystem of wildlife? & 3.3929 & .80178 \\
\hline Are you aware about the wildlife of our country? & 1.6071 & .82415 \\
\hline Do you think we need to preserve Wildlife to promote Domestic Tourism? & 1.2679 & .64642 \\
\hline Can domestic tourism exist without wildlife? & 2.1071 & .67900 \\
\hline
\end{tabular}

Table 2: Descriptive statistics

Table 2 represents the descriptive statistics which are mean value, standard deviation of the variables. Here all the variables are much diversified as there are various different values of mean which goes up to 4 and the standard deviation is less than 1 . This indicates respondents had very different 
approaches to the statements. Most of the respondents strongly agreed with" Domestic tourism is interrupting the ecosystem" as mean is above 3 and respondents strongly disagreed with "Aware about wildlife as mean is 1 . The standard deviation is also below 1 on a few variables which indicates the respondents more or less agreed and disagreed with the variables.

\section{Discussions and Conclusion}

This study was conducted on the basis of Bangladesh. This study indicates the gap between wildlife and society, especially tourism. Due to covid-19 WHO (World Health Organization) said that international tourism has been kept at halt. It has been decided that international tourism will be kept at halt till 22 and if covid-19 does not end the decision might get changed and the time might get longer. Usually when an epidemic happens the world changes the way of living and adjusts with the new flow. Bangladesh has also taken that step. This study has shown that some small steps made a huge change on domestic tourism. It improved by a good margin. But for some reasons Bangladesh is yet to provide the safety for wild animals. Some of the initials have already taken such as animal abuse into account and started to make various important changes. Besides those complications, Bangladesh has taken different steps to improve its domestic tourism and that's when the term "Coexistence of wildlife with modern tourism" comes. For the past few years, many small businesses have started to build a great reputation for domestic tourism, and they have taken some initiative to educate the tourists for the sustainability of wildlife. They have made guidelines which are good for the locals as well as good for nature itself. From the study it has been found that the tourists and the locals are not yet aware of the situation. Pollution is one of the main concerns and it might cause severe problems in future. It shows that the majority of the people who are thought to be future tourists or those who are expected, or potential tourists are unaware of the term sustainable tourism. Sustainable tourism comes here as it includes all the key terms which are, "Modern Tourism, Domestic Tourism, Wildlife, and Nature. But setting aside sustainable tourism, we have an important matter which is the coexistence of wildlife. It is essential for the economy and the standardization of the tourism industry here in Bangladesh. Naturally, people in Bangladesh or the locals don't know how to reserve wildlife or how it can be used or sustained.

\section{Steps and initiative}

There are some steps which are visible, and some are invisible. We have to change the idea of rebirth of wildlife or eco-friendly nature. The visible steps are given in a figure below:

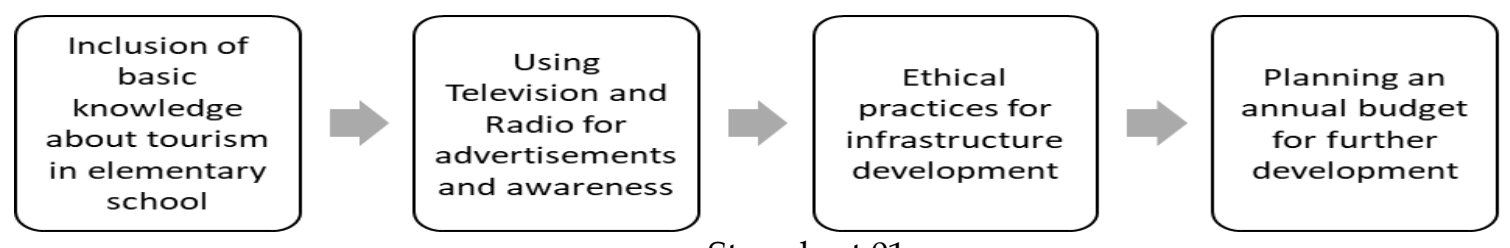

Step chart 01

This study shows that Bangladesh has yet to learn the process of sustaining wildlife and developing tourism. Infrastructural development usually creates a lot of pollution and disruption on nature which affects directly to the wildlife. It can kill a river and also can demolish a forest. Infrastructural development is essential but for the sake of wildlife we have to create new improved ways.

Moreover, after opening a natural place for tourism people often use it differently rather than maintaining guidelines. Thus, we have to make few rules specifically for destinations which might lead to less pollution and disasters. This study shows local communities have knowledge about tourism but still have not accepted it. But that is only for international tourism. For domestic tourism, local people are very much hospitable. Rather than local people, tourism and tourism development are causing imbalance of the natural flow of wildlife and wildlife structure.

\section{Limitation and direction for future research Limitation}

This study has many limitations as the study was conducted based only on the local and tourists. Fractions of information are out there to study, rather using total secondary data it was the first initial study of domestic tourism related to wildlife in the context of Bangladesh. The local people are still 
conservative thus it becomes a great problem to conduct study. Many of the respondents tried to skip the questionnaire which caused problems in collecting data. Most of the data is collected from students and job holders. So, biasness was observed there. The study also can be further carried out using more statistical tools and diversified samples.

\section{Direction for future research}

Though, this research is conducted on primary data. In future the secondary data might be available for further data collection. The current condition of our society is very much changing rapidly with regular development of the world. Bangladesh is also adapting various new methods and areas which might lead to success in the near future. This study represents the condition of Bangladesh as it has been conducted through various subjects and samples. The study argues with the current system and steps of sustaining wildlife with tourism. It argues with the impact and comparative advantages. This study was initially conducted to find out the acceptability of the idea and indicates new directions and perspectives. It might get lots of qualitative research on some key elements such as ethical development, wildlife friendly environment and aware tourists. This might help gather the initial thinking of the local wildlife.

\section{References}

Philip J. Nyhus, 2016 Human-Wildlife Conflict and Coexistence, Annual Review of Environment and Resources 41:1, 143-171

Woodroffe R, Thirgood S, Rabinowitz A, eds. 2005. People and Wildlife: Conflict or Coexistence? Cambridge, UK: Cambridge Univ. Press Landmark edited volume covering human-wildlife conflict and coexistence.

Soulsbury CD, White PCL. 2015. Human-wildlife interactions in urban areas: a review of conflicts, benefits, and opportunities. In Wildlife Research: Interactions Between Humans and Wildlife in Urban Areas, ed. A Taylor, P White, pp. 541-53. Australia: CSIRO

Conover MR. 2002. Resolving Human-Wildlife Conflicts: The Science of Wildlife Damage Management. Boca Raton, FL: CRC Press Comprehensive summary of animal damage management.

Kate Rodger, Susan A. Moore \& David Newsome (2010) Wildlife Tourism Science and Scientists: Barriers and Opportunities, Society \& Natural Resources, 23:8, 679-694, DOI: 10.1080/08941920802438600

(Paul C Reynolds, Dick Braithwaite, 2001, Towards a conceptual framework for wildlife tourism, Tourism Management, Volume 22, Issue 1, Pages 31-42, ISSN 0261-5177)

Susanna Curtin (2009) Wildlife tourism: the intangible, psychological benefits of human-wildlife encounters, Current Issues in Tourism, 12:5-6, 451-474, DOI: 10.1080/13683500903042857

Beatrice Frank (2016) Human-Wildlife Conflicts and the Need to Include Tolerance and Coexistence: An Introductory Comment, Society \& Natural Resources, 29:6, 738-743, DOI: 10.1080/08941920.2015.1103388

Moren Tibabo Stone \& Gyan P. Nyaupane (2018) Protected areas, wildlife-based community tourism and community livelihoods dynamics: spiraling up and down of community capitals, Journal of Sustainable Tourism, 26:2, 307324, DOI: 10.1080/09669582.2017.1349774

Susanna Curtin (2005) Nature, Wild Animals and Tourism: An Experiential View, Journal of Ecotourism, 4:1,115, DOI: $10.1080 / 14724040508668434$

Ryan Plummer \& David A. Fennell (2009) Managing protected areas for sustainable tourism: prospects for adaptive co-management, Journal of Sustainable Tourism, 17:2, 149-168, DOI: 10.1080/09669580802359301 